\title{
Development Ethics Of Sunday School Children Through The Teaching Creativity Of Teacher
}

\author{
Hisardo Sitorus, Andar Gunawan Pasaribu \\ Institut Agama Kristen Negeri Tarutung \\ E-mail hisardositorus@yahoo.co.com; E-mail address pdt.andargunawanpasaribu@yahoo.co.id
}

\begin{abstract}
There are 4 main points to be addressed clearly in abstract section: (1) background of research title, (2) research purpose, (3) research methodology, and (4) research result/contribution. Background section should be the shortest part of the abstract and should very briefly outline the following information: What is already known about the subject, related to the paper in question? What is not known about the subject and hence what the study intended to examine (or what the paper seeks to present-purpose). In most cases, the background can be framed in just 2-3 sentences, with each sentence describing a different aspect of the information referred to above. The purpose of the research, as the word itself indicates, is to provide the reader with a background to the study, and hence to smoothly lead into a description of the methods employed in the investigation. The methodology section is usually the second-longest section in the abstract. It should contain enough information to enable the reader to understand what was done, and important questions to which the methods section should provide brief answers. The results section is the most important part of the abstract and nothing should compromise its range and quality. The results section should therefore be the longest part of the abstract and should contain as much detail about the findings as the journal word count permits.
\end{abstract}

Keywords: Creativity Teachers. Christian Ethics of Sunday school

\section{INTRODUCTION}

Sunday school children are multi-dimensional individuals who have emotional, spiritual, mental, will, and physical aspects. Since he has a spiritual aspect, his needs should be met. The presence of God through His Spirit in the child's life, of course, will answer the fulfillment of that spiritual need. This spiritual need is met if the child has a living relationship with God through Jesus Christ. When children are guided to open their hearts to the Lord Jesus Christ, who has sacrificed for their sins, an attitude of fear and respect for God and His Word grows slowly, which is strengthened by the spiritual education they receive. This experience will have a positive impact on the growth and development of children's behavior.

Setiawan (2005: 10), in his book, states that one of the duties of Sunday school teachers is teaching. In the teaching and learning process, the teacher must be able to bring about changes in students, for example, changes in knowledge, attitudes, and behavior. In the sense that the Christian education provided by the Sunday school teacher can foster Sunday school children so that they have a Christian character. If a Sunday school child knows who Jesus is and has accepted Him as a living Savior, then one day, he will continue to believe and have full confidence in Jesus as the living Savior. 
Thomson said: The premise is that teaching creativity through science is a good learning motivator and can lead to more meaningful science learning. Included is a model for teaching creative thinking through science with examples that show how a teacher can, at a minimum, start with an established series of inquiry lessons and incorporate more creative thinking (2017;29-42). Then Siswanto said: the ability of a Sunday school teacher is an ability determined and given by God through the teacher's learning process, just like a construction expert who lays a solid foundation of Jesus Christ for children as a provision for a glorious future (2008: 18).

\section{LITERATURE REVIEW}

\section{II.1. Sunday School}

According to Kadarmanto, the first Sunday school was born on September 14, 1735, by Robert Raikes. (2012: 26), Around the 18th century, to change the bad behavior of children, he often saw when the day was off from working as a factory worker. On Sundays, they have the freedom to play to their heart's content and act as they please and make other people feel annoyed. After a long process, Robert Raikes' hard work was successful. The children who he coached through the teacher who he asked to teach them every week have produced results. They have changed from behavior that was bad to be better. This makes the actions taken by Robert Raikes have a very good impact on building behavior and impart knowledge to the children around him. These Sunday school services need to be improved by Sunday school teachers along with the development of times, technology, and increasingly modern civilization. Sunday school teachers hold the duties of educators, mentors, and teachers of children about the truth of God's word.

\section{II.2. The Morality Teachers of Sunday School}

Christianity, along with other monotheistic world religions, teaches there is a God who possesses final moral authority. In the biblical account, God is, by nature, good, and the presence of moral concepts in the created world is based on God's moral character. (Heller, 2019). The Sunday school teacher is one of the most important figures in giving teaching assignments related to Christian Religious Education. Siswanto (2008: 18) says that: The ability of a Sunday school teacher is a teaching ability that is established and given by God, just like a construction expert who lays a solid foundation for children about Jesus Christ as a provision for a glorious future. Furthermore, Laheba (2007: 16), in his book, states that Sunday school teachers are partners of God in educating children in Christian Religious Education (PAK) for the implementation and fulfillment of the Kingdom of God. Furthermore, Leo (2008: 3) argues that: Sunday School teachers are former Sunday School students or congregations who are called to serve (true, committed servants).

Morality with the symptoms it experiences will be seen from several aspects of morality. According to Gunarsa (2007: 61), morality includes customs or habits, then Brownlee (1996: 147) says language courtesy. Further, Suseno said Sunday school teachers must always act honestly, humbly, and politely. Said honesty and humility (1986: 141).

According to Setiawan said: the eight requirements of a Sunday school teacher must be: a person who was born again/saved, a Growing Christian, Christian Faithful to the Church, Someone Who Understands That Education Ministry is God's Call, A person who likes the object he teaches, A Man Who Is Good In His Life Testimony, One Who Has Received Basic Training as a Teacher, Person Who Serves By Relying on the Power of the Holy Spirit (2005: 7-9). Furthermore, Siswanto said there are four faith-related morality teachers include: must have faith in God, faith in Bible Teaching, faith in God's call, and must have a good personality. (2012: 21). 


\section{II.3. Teaching Creativity of Teacher}

Teachers' teaching creativity can influence the ethics of Sunday school children. According to Paulus, said seventh creativity of teacher :

1. Prepare every meeting every Sunday with various creative events/songs/stories/activities so that Sunday

2. Follow teaching preparation as diligently as possible with creativity.

3. Make the best possible props.

4. Make a varied classroom layout so as not to be monotonous.

5. Prepare creative children's activities that develop all children's potential.

6. A teacher must also be diligent in creativity in attending seminars, teaching training.

7. the direction of coaching and the right model of coaching with creativity. (2003: 123-124).

Then. Kadarmanto said three important things are the main task of the Sunday school teacher or servant, namely: Communicating the right things, being a channel of blessings, and serving according to their respective abilities(2005: 9-10). Furthermore, according to Setiawan said There are seven obligations of teachers with creativity there are seven duties/obligations that are teaching, Shepherd, fatherhood Set an Example, Evangelizing, Pray and Seizing Opportunities (2005: 10-12).

From the various opinions of these experts, it is understood that what is the morality of Sunday school teachers can be understood or embodied as what is contained in the duties, obligations, and requirements of Sunday school teachers, namely communicating the correct things according to what is written in the Bible through teaching or evangelism, and must be an example for their students and become a channel of blessings that bring joy.

\section{II.4. Christian Ethics}

J. Douma (2010: 1) said that ethics is a theological science that investigates all aspects of human behavior from a "good" or "bad" perspective. Ethics not only describes all kinds of human actions (descriptive) but also assesses and considers whether human behavior is acceptable or not. In the end, Ethics provides man with guidelines for his way of life (prescriptive). K. Bertens said that "Ethics" means knowledge of what is commonly done or knowledge of customs. "(2011: 4). Another way of formulating the same thing is that ethics is the science which investigates moral behavior. Phil Eka Darmaputera said: "Ethics is a science or study of norms that regulate human behavior"(1992: 5). According to Abineno said: "Ethics is defined as knowledge or teachings about human actions (deeds) which are judged based on an ethical norm." We can also define differently what is discussed in ethics in the form of questions: what is good and what is bad, about what is right and what is bad(2010:

Abilene said: "Christian ethics depart from the law of God and therefore heteronomous"(2010: 14). In connection with the above opinion, Brownlee said: "Christian ethics is an investigation of what is good or right and what is bad and wrong in human behavior and characteristics. In other words that are often used for ethics is morality"(2010: 14). Within this context, the goal of ethics education was to strengthen students' ability to recognize and respond to ethics issues so they will be best able to apply their ethical philosophy to their decision making (Rashmi; 2011). Then A subset of ethical education is moral education, which focuses on developing student abilities to apply moral thinking by improving ethical sensitivity and empathetic understanding of other people ( Swanson;2015)

Then Alexis said: There are people who - either spontaneously or through some strenuous inner exercise of prayer or meditation- can temporarily project their consciousness upwards along a specific line corresponding to their type and way of functioning towards the levels of the superconscious, getting at times very near to the spiritual(2015;44 ). Christian Ethics is a science or study that investigates all human behavior from a good or bad perspective or science that investigates moral behavior based on the Bible or God's truth. 


\section{RESEARCH METHODOLOGY}

This research was conducted using descriptive quantitative research methods that are correlational. The research location is in the Protestant Church (GPP) Region III North Tapanuli - Humbang Hasundutan. The research time includes the preparation of research proposals for June 2020 and discussion of research results from August to October 2020.

Respondents of this study were 45 teachers of Sunday school in the Protestant Communion Church (GPP) Region III with the following data: (Data source from almanac and regional coordinator of GPP Region III of 2015). Development Ethics for Sunday School Children, namely thoroughly teaching creativity: song, activity, story, preparing, make best-probing props, variety classroom, attending the seminar, training, and creativity model teaching.

This research method uses the product moment method and the alpha formula Arikunto.(2010; 213 dan 171). Then to find out the level of reliability of the instrument, the price of $\mathrm{r} 11$ is consulted by interpreting the calculated correlation index with a simple interpretation as said by Arikunto, namely:

$$
\begin{aligned}
& 0.800-1.00=\text { High } \\
& 0.600-0.800=\text { Enough } \\
& 0.400-0.600=\text { Slightly Low } \\
& 0.200-0.400=\text { Low } \\
& 0.000-0.200=\text { Very low }(2010: 319)
\end{aligned}
$$

From the results of the reliability test $\mathrm{r} 11=0.980$ (high interpretation), the calculations are in appendix V.

\section{FINDING AND DISCUSSION}

By knowing $t$ count $=3,623$ with $t$ table based on the degrees of freedom (DK) which is $n-1$, namely 45 $1=44$. If the error level $(\alpha)$ is set at $5 \%$, while the test is carried out using the one-party test, then the price of the $t$ table is 1.684 . For more details, see the curve below:

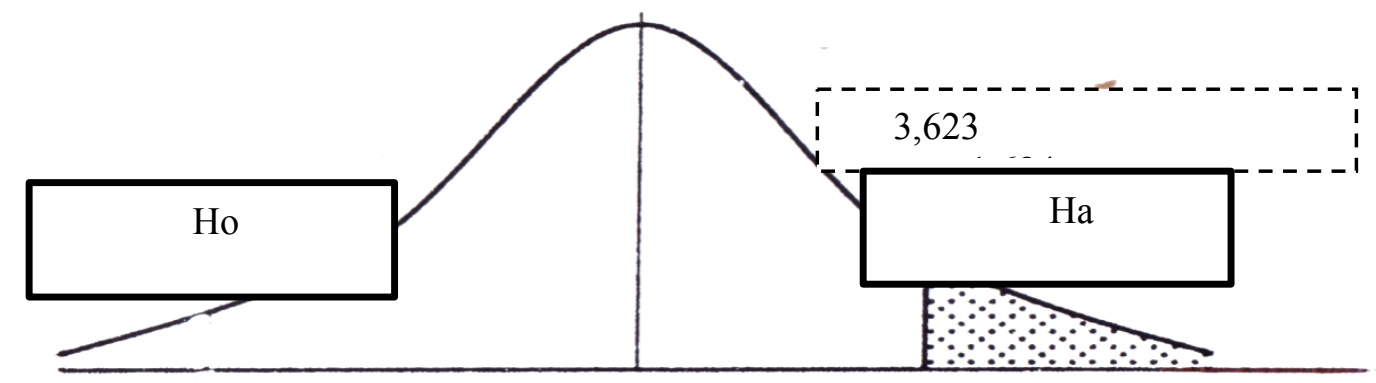

Figure 1. Curve

In the curve figure, it can be seen that the $t$ count is greater than the $t$ table price or falls in the receiving area $\mathrm{Ha}(3,623>1,684)$ then $\mathrm{Ha}$ is accepted, and Ho is rejected, namely the creativity Analysis of Sunday School Teachers in Christian Ethics Review in $2020 \geq 70 \%$ of expected.

From the data processing that has been, the researchers tested the proposed hypothesis, namely the Ability teaching creativity of Sunday School Teachers in Christian Ethics Review in GPP Region III 5 $\geq 70 \%$ of expected so that the hypothesis can be accepted. 
Hypothesis Formulation:

Ha: The teaching creativity of Sunday School Teachers in Christian Ethics Review $\geq 70 \%$ of the expected.

H0: teaching creativity of Sunday School Teachers in Christian Ethics $<70 \%$ of the expected.

Ha: $\mu 0 \geq 70 \%$ (Greater or equal)

H0: $\mu 0<70 \%$ (Smaller 70\%)

Concerning the criteria for acceptance or rejection of the hypothesis based on data processing that has been carried out by the researcher by obtaining the $t$ count $=3,623$, it is consulted with the t-table $=$ 1.684 with thus the table value. So it can be concluded that Ha, which states the Ability teaching creativity of Sunday School Teachers in Christian Ethics Review $\geq 70 \%$ of what is expected, the hypothesis can be accepted.

Based on the results of research on the teaching creativity of Sunday School Teachers in the Christian Ethics $\geq 70 \%$ of the expected, it is known that the comparison between the count and the table is $t$ count $=3,623>$ ttable $=1.684$ with the average manual calculation for each is: creativity song, story, and activity $76 \%$, Variety classroom $74 \%$, make best probing props $70 \%$, and creativity approach and model in seminary, training $74 \%$. This can be a bar chart right with:

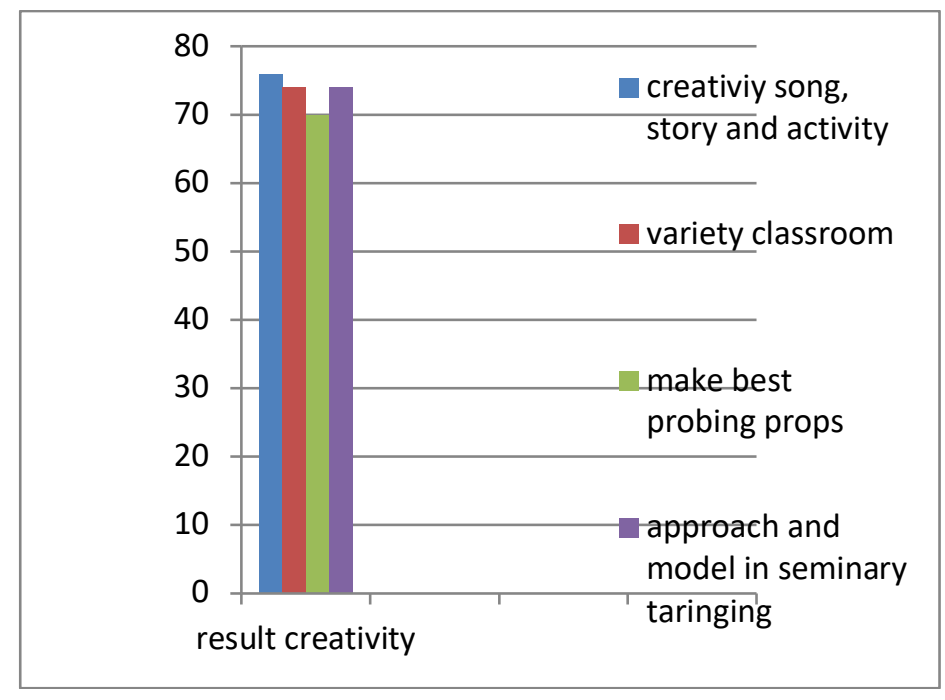

Figure 2. Bar Chart

The overall manual average calculation is $73,5 \%$. So the teaching creativity of Sunday School Teachers in Christian Ethics Review $\geq 70 \%$ of the expected, it can be concluded that the creativity of Sunday school teachers in the Christian ethics review is Good.

Next, Brown said: Being aware of a child as he really is is half the battle toward effective and creative teaching, especially in terms of relevant curriculum content and teacher behavior.( 2015;215). Then Feldhusen said: They stressed their need for materials related to the students' backgrounds and interests and audio-visual materials with concrete, manipulative opportunities for the student $(1975 ; 1162)$. Teachers can develop the ethics of Sunday school children through creative teaching and morality. An ethical child is a child who acts good, is polite, humble, and loves. 


\section{CONCLUSION AND FURTHER RESEARCH}

From the research results, the creativity of teaching teachers can improve the ethics of Sunday school children. The creativity of teacher include prepare every meeting every Sunday with various creative events/songs/stories/activities, so that Sunday, follow teaching preparation as diligently as possible with creativity, make the best possible props, make a varied classroom layout so as not to be monotonous, prepare creative children's activities that develop all children's potential, creativity in attending seminars, teaching training, teacher training, and so on, and the direction of coaching and the right model of coaching with creativity. Plus, if teachers have morality ( among others: Born Saved and Growing Up, A Christian Faithful to the Church, Good in the Testimony of His Life, Understanding that the Ministry of Sunday School Teachers is a call of God based on the power of the Holy Spirit, A Person Who Loves the Objects He Educates) the children more ethical.

\section{REFERENCES}

Abineno, C. (2010). Sekitar Etika dan soal soal Etika. Jakarta: BPK Gunung Mulia .

Ainleya, M. *. (2013). A Cultural Perspective on the Structure. International Journal of Science Education, 51-71.

Azhar, A. (2011). Media Pembelajara. Jakarta: Grafindo .

Bie, A. I. (2015). teaching creativity -. Gifted Education tnternations/1985 Vo/3, pp 43-46, 44.

Boeve, L. (2012). Religious education in a post-secular and post-Christian context. Journal of Beliefs \& Values: Studies in, 155.

Brown, G. I. (2015). Teaching Creativity to Teachers and Others. Journal of Teacher Education, vol. 21, 2, download sage 2015, 210-216.

Brownlee, M. (1966). Pengambilan Keputusan Etis dan Faktor faktor di dalamnya. Jakarta: BPK Gunung Mulia.

Casson, A. \&. (2019). Religious Education for Spiritual Bricoleurs? the. Journal of Beliefs \& Values, 3.

Chinta, R. H. (2011). The Effect of Pedagogy on Students' Perceptions. ETHICS \& BEHAVIOR, 2, Taylor \& Francis Group, LLC, 107.

D.Singgih, G. (1997). Dasar dan Teori Perkembangan . Jakarta: BPK.Gunung Mulia.

D.Singgih, G. (2007). Psikologi Perkembangan . Jakarta: BPK.Gunung MUlia .

Frans, M. S. (1986). Kuasa dan Moral . Jakarta : Kanisius.

Ge, Z. G. (2019). Does mismatch between learning media. Interactive Learning Environments, Routledge Francis Taylor, 1-17.

J, D. (2010). Kelakuan Yang Bertanggung Jawab . Jakarta: BPK. Gunung MUlia.

J. Philip, C.B. Rao, T. Jayakumar, B. Raj. (2000). A New Optical Technique for Detection of Defects in Ferromagnetic Materials and Components. NDT\&E International, (hal. 289-295).

J. Ramírez A., and A. Rubiano F. (2011). Optimization of Inverse Kinematics of a 3R Robotic Manipulator using Genetic Algorithms. World Academy of Science, Engineering and Technology 59, (hal. 1425-1430).

Johnson, P. (2012, June). diambil kembali dari Biology Terms - Glossary of Biology Terms and Definitions: http://www.buzzle.com/articles/biology-terms-glossary-of-biology-terms-anddefinitions.html

K, B. (2011). Etika. Jakarta : Gramedia Pustaka Umum .

Kadarmanto, R. S. (2009). Pendidikan Agama Kristen. Jakarta: BPK.Gunung Mulia.

Paulus, L. (2003). Teknik Kreaif dan Terpadu Dalam Mengajar Sekolah Minggu. Yogyakarta: Andi .

Rusman. (2011). Model Model Pembelajaran Mengembangkan Profesionalisme Guru . Jakarta: Rajagrafindo .

Sijabat, B. (2010). Mengajar Secara Profesional . Bandung : Kalam Hidup . 
Skinner, E. A. (2012). Intrinsic Motivation and Engagement. The Journal of Environmental Education, Publisher: Routledge, 16-36.

Soltesova, V. \&. (2020). The Influence of Religious Education on the. Religious Education, 1-13.

Stover, M. (2016). Marginally Good:. Journal of Religious \& Theological Information, 51-64.

Suharsimi, A. (2010). Prosedur Penelitian . Jakarta: Rineka Cipta.

Susanto, L. (2008). Kiat Sukses Mengelola dan Mengajar Sekolah Minggu. Yogyakarta: Andi .

Swanson, D. (2015). Fictional Stories With Ethical Content: Guidelines for. ETHICS \& BEHAVIOR, Taylor \& Francis Group, LLC, 7.

Thesndun, L. (1997). Pendidikan Agama Kristen. Solo : Penerbit Solo

Thomson, T. (2017). Teaching Creativity Through Inquiry Science . GIFTED CHILD TODAY, 27-42.

Treffinger, J. F. (1975). Teachers' Attitudes and Practices in Teaching Creativity and Problem-Solving to Economically Disadvantaged and Minority Children. Psychological Repom, 1162. 